\title{
Acidic reaction products of monoterpenes and sesquiterpenes in atmospheric fine particles in a boreal forest
}

\author{
M. Vestenius ${ }^{1}$, H. Hellén ${ }^{1}$, J. Levula ${ }^{2}$, P. Kuronen ${ }^{1}$, K.J. Helminen ${ }^{3}$, T. Nieminen ${ }^{2}$, M. Kulmala ${ }^{2}$, and H. Hakola \\ ${ }^{1}$ Finnish Meteorological Institute, Atmospheric Composition Research, P.O. Box 503, 00101 Helsinki, Finland \\ ${ }^{2}$ Department of Physics, P.O. Box 64, University of Helsinki, 00014 Helsinki, Finland \\ ${ }^{3}$ Department of Chemistry, P.O. Box 55, University of Helsinki, 00014 Helsinki, Finland
}

Correspondence to: M. Vestenius (mika.vestenius@fmi.fi)

Received: 18 December 2013 - Published in Atmos. Chem. Phys. Discuss.: 28 January 2014

Revised: 16 June 2014 - Accepted: 17 June 2014 - Published: 8 August 2014

\begin{abstract}
Biogenic acids were measured in aerosols at the SMEAR II (Station for Measuring Forest EcosystemAtmosphere Relations II) station in Finland from June 2010 until October 2011. The analysed organic acids were pinic, pinonic, caric, limonic and caryophyllinic acids from oxidation of $\alpha$-pinene, $\beta$-pinene, limonene, $\Delta^{3}$-carene and $\beta$ caryophyllene, respectively. Due to a lack of authentic standards, the caric, limonic and caryophyllinic acids were synthesised for this study. The mean, median, maximum and minimum concentrations $\left(\mathrm{ng} \mathrm{m}^{-3}\right)$ were as follows: limonic acid $(1.26,0.80,16.5$, below detection limit $(<\mathrm{LOD}))$, pinic acid (5.53, 3.25, 31.4, 0.15), pinonic acid (9.87, 5.07, 80.1, < LOD), caric acid (5.52, 3.58, 49.8, <LOD), and caryophyllinic acid $(7.87,6.07,86.1,<\mathrm{LOD})$.

The highest terpenoic acid concentrations were measured during the summer. Of the acids, $\beta$-caryophyllinic acid showed the highest concentrations in summer, but during other times of the year pinonic acid was the most abundant. The $\beta$-caryophyllinic acid contribution was higher than expected, based on the emission calculations of the precursor compounds and yields from oxidation experiments in smog chambers, implying that the $\beta$-caryophyllene emissions or $\beta$-caryophyllinic acid yields were underestimated. The concentration ratios between terpenoic acids and their precursors were clearly lower in summer than in winter, indicating stronger partitioning to the aerosol phase during the cold winter season. The $\beta$-caryophyllinic and caric acids were weakly correlated with the accumulation-mode particle number concentrations.
\end{abstract}

\section{Introduction}

Large amounts of biogenic volatile organic compounds (BVOCs) (isoprene, monoterpenes and sesquiterpenes) are emitted into the atmosphere by vegetation, especially in the densely forested boreal regions (Hakola et al., 2001, 2006; Tarvainen et al., 2005, 2007; Hellén et al., 2006; Wiedinmyer et al., 2004; Steiner and Goldstein, 2007). In the atmosphere, these compounds are oxidised, resulting in reaction products, e.g. acids and carbonyl-containing compounds that participate in the formation and growth of new particles (Kulmala et al., 2004; Tunved et al., 2006). Current estimates suggest that global biogenic secondary organic aerosol (SOA) sources are larger than anthropogenic sources (Hallquist et al., 2009). Even though organic compounds account for $20-90 \%$ of the total fine particle mass concentration in a wide variety of atmospheric environments (Kanakidou et al., 2005), little information is available on their detailed composition.

In smog chamber studies, the SOA yields for the various hydrocarbons and even for the monoterpenes vary considerably (Griffin et al., 1999; Yu et al., 1999; Jaoui et al., 2003; Lee et al., 2006). The produced compounds have very different vapour pressures, and partitioning between the gas and aerosol phases varies widely. Detailed knowledge of the occurrence of individual compounds is therefore essential for atmospheric studies.

Some studies have focused on the concentrations of the reaction products of $\alpha$ - and $\beta$-pinene (pinonic and pinic acids) in real atmospheres (Kavouras and Stephanou, 2002; Kourtchev et al., 2008, 2009; Zhang et al., 2010; Cheng et al., 2011; Kristensen and Glasius, 2011), but very little 
information is available on the concentrations of other terpenoic acids, mainly due to the lack of authentic standards. In some studies, the concentrations of other terpenoic acids were estimated by indirect calibration methods (GomezGonzalez et al., 2012; Fu et al., 2009; Warnke et al., 2006). Sesquiterpene products are especially interesting, because their parent compounds are often too reactive to be measured in ambient air. $\beta$-caryophyllene was the main sesquiterpene in many emission studies in boreal forests (Hakola et al., 2006; Tarvainen et al., 2005), but it has never been detected in the ambient air, due its high reactivity. $\beta$-caryophyllene could be a major source of SOA, due to its reactivity and high aerosol yields in smog chamber studies (Jaoui et al., 2003; Lee et al., 2006; Chen et al., 2012).

In this study, specific acid reaction products of BVOCs, which affect the formation and growth of fine particles, were analysed from ambient aerosols in boreal forests. Fine particle filter samples were taken at the SMEAR II (Station for Measuring Forest Ecosystem-Atmosphere Relations II; Hari and Kulmala, 2005) station in Finland from June 2010 until October 2011.

\section{Experiments}

\subsection{Sampling}

The measurements were conducted at the SMEAR II station $\left(61^{\circ} 51^{\prime} \mathrm{N}, 24^{\circ} 18^{\prime} \mathrm{E}, 181 \mathrm{~m}\right.$ above sea level, a.s.l. $)$ at Hyytiälä, southern Finland (Hari and Kulmala, 2005). The largest nearby city is Tampere, with 200000 inhabitants. It is located $60 \mathrm{~km}$ to the southwest of the site. The most common vegetation at the sampling site is a homogeneous Scots pine (Pinus sylvestris L.) forest, with some birches (Betula) and Norway spruces (Picea abies) growing nearby.

The aerosol samples were collected, using pumped sampling from June 2010 until October 2011, from the particulate matter $\mathrm{PM}_{2.5}$ fractions in air onto quartz filters (Pallflex Tissuquartz 2500QAT-UP, internal diameter i.d. $47 \mathrm{~mm}$; Pall Corp., Port Washington, NY, USA). A total of 86 samples was collected. Before sampling, the filters were heated to $600^{\circ} \mathrm{C}$ for over $8 \mathrm{~h}$. Occasionally, we used an additional backup filter, but no breakthrough was observed. Airflow through the filters was $161 \mathrm{~min}^{-1}$. The collection times were 1-7 days per filter. The sampling dates are shown in Table 3. Longer, 7-day samples were collected during winter, due to expected low concentrations. Shorter, 1-3-day samples were collected during summer for better time resolution. Threeday samples were collected during the weekends. When calculating the monthly mean values, the samples were considered to belong to the month where most of the sampling took place. The gases were removed from the airflow before the filters, using a parallel-plate carbon denuder (Sunset Laboratory Inc., Portland, OR, USA). The efficiency of the denuder was checked by taking samples of VOCs (aromatic hydrocar- bons and monoterpenes) more volatile than those measured in this study, using pumped adsorbent tube sampling and thermal desorpter-gas chromatography-mass spectrometry (TD-GC-MS) analysis. Aromatic hydrocarbons (benzene, toluene, ethylbenzene and xylene), as well as monoterpene traces, were negligible after the denuder. The $\mathrm{PM}_{1}$ concentrations were measured using Dekati model $\mathrm{PM}_{10}$ impactors (Dekati, Tampere, Finland) at the same site and time period as the terpenoic acids.

\subsection{Sample preparation and analysis}

The samples were extracted into $50 \mathrm{ml}$ of methanol (J.T.Baker 8402; Mallinkrodt Baker, now Avantor Performance Materials Inc., Center Valley, PA, USA), using an ultrasonic bath for $90 \mathrm{~min}$ and then evaporated into $1 \mathrm{ml}$ of volume using a Büchi Syncore evaporator (Büchi Labortechnik AG, Flawil, Switzerland), and further evaporated into $100 \mu \mathrm{l}$ under nitrogen flow. The samples were analysed using highperformance liquid chromatography with electrospray ionisation and an ion trap mass spectrometer (HPLC-ESI-ITMS) (Agilent 1100 Series LC/MSD Trap; Agilent Technologies, Santa Clara, CA, USA) in negative-ion mode. The column used was a Waters XTerra ${ }^{\circledR} M S C_{18}(3.5 \mu \mathrm{m}, 2.1 \times 150 \mathrm{~mm})$ (Waters Corp., Milford, MA, USA). The main components of the mobile phase were MilliQ water (Millipore Corp., Billerica, MA, USA) and acetonitrile (ACN) (VWR HiPerSolv Chromanorm; VWR International, Radnor, PA, USA). The $\mathrm{pH}$ of the mobile phase was adjusted to $\sim 3$ with acetic acid (Fluka, 99.5\%). The 80 min-long gradient programme was initiated with $95 \%$ water and $5 \% \mathrm{ACN}$, and after 5 min the $\mathrm{ACN}$ was gradually increased to $8 \%$ at $10 \mathrm{~min}$. After $10 \mathrm{~min}$, the ACN concentration was held at $8 \%$ until $40 \mathrm{~min}$, and thereafter quickly increased to $90 \%$ at $45 \mathrm{~min}$ and to $95 \%$ at $50 \mathrm{~min}$. The concentration was then held constant until $70 \mathrm{~min}$ and later decreased to $5 \%$ at $71 \mathrm{~min}$ and held at $5 \%$ until the end of the run. The column was held at a constant temperature of $65^{\circ} \mathrm{C}$. The samples were analysed using external standards on a four-point calibration curve representing the entire measurement area. The uncertainty of the analysis based on duplicate analysis was less than $50 \%$, close to the detection limits and less than $20 \%$ for higher concentrations. Camphoric acid was used as an internal standard to correct for losses in sample preparation, matrix effects and changes in the sensitivity of the instrument. The concentrations of the analytes in the samples varied between below the detection limit and $145 \mathrm{ng} \mathrm{m}^{-3}$. The limit of detection was calculated using the standard deviation of the blank samples, and was typically from 0.1 to $0.8 \mathrm{ng} \mathrm{m}^{-3}$, being lowest for the limonic acid. The variation was lower within compounds than between compounds. Each of the compounds was measured individually, using the mass spectrometer's scan mode to determine the retention times and representative ions for each compound from the standard solution. In the analysis runs, the detector was used in multiple reaction monitoring 


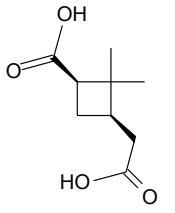

Pinic acid

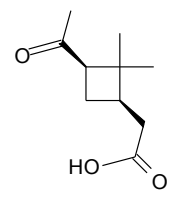

cis-Pinonic acid<smiles>C=C(C)[C@H](CCC(=O)O)CC(=O)O</smiles>

Cis-3-caric acid

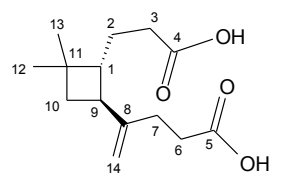

$\beta$-Caryophyllinic acid
Figure 1. Structures of (a) commercially available and (b) synthesised terpenoic acids. The numbers refer to the $\mathrm{C}$ atoms in the NMR spectra.

(MRM) mode, in which each compound was monitored in its own retention time window, using its representative ion.

\subsection{Synthesis of cis-3-caric, limonic and $\beta$-caryophyllinic acids}

We selected the main acid products (e.g. Yu et al., 1999; Jaoui et al., 2006) of the most common monoterpenes ( $\alpha$ pinene, $\beta$-pinene, 3 -carene, limonene) and the most common sesquiterpene, i.e. $\beta$-caryophyllene, emitted in boreal forests (Tarvainen et al., 2007), as the target compounds of the study. The pinic and pinonic acids were commercially available, but the $\beta$-caryophyllinic acid, cis-3-caric acid and limonic acid (Fig. 1) were synthesised at the Laboratory of Organic Chemistry, University of Helsinki.

The nuclear magnetic resonance (NMR) spectra were recorded on a Varian Unity Inova 500 spectrometer (Varian Medical Systems, Palo Alto, CA, USA). The mass spectra were obtained with a Bruker microTOF (ESI-timeof-flight, ESI-TOF) (Bruker Corp., Billerica, MA, USA) or JEOL JMS-700 (electron ionisation-MS, EI-MS) (JEOL Ltd., Tokyo, Japan) instruments. The infrared (IR) spectra were recorded on a Bruker Alpha-P Fourier transform IR (FT-IR) instrument. The melting points (Mp) were determined in open capillary tubes with a Büchi B-545 apparatus.

Cis-3-caric acid was prepared from delta-3-carene (Aldrich, $95 \%$ purity; Sigma-Aldrich, St. Louis, MO, USA) by $\mathrm{RuCl}_{3}$-catalysed oxidation with $\mathrm{NaIO}_{4}$ (Aldrich) to cis3-caronic acid (Nair et al., 2010) and subsequent haloform reaction with $\mathrm{NaOBr}$ in aqueous $\mathrm{NaOH}$ (Semmler and von Schiller, 1927) to the final product. The product was purified by recrystallisation from cyclohexane-toluene-isopropanol to give a white powder with a $10 \%$ overall yield and $95 \%$ purity (estimated by NMR); Mp. (Melting point) $109-112^{\circ} \mathrm{C}$ (in literature $112-113^{\circ} \mathrm{C}$; Semmler and von Schiller, 1927). ${ }^{1} \mathrm{H} \mathrm{NMR}\left(\mathrm{CDCl}_{3}, 500 \mathrm{MHz}\right) \delta: 12.22(\mathrm{br}, 2 \mathrm{H}, 1$ and 6
$\mathrm{COOH}), 2.62(\mathrm{dd}, \mathrm{J}=17 \mathrm{~Hz}, 3.5 \mathrm{~Hz}, 2 \mathrm{H}, 2$ and 5), $2.03(\mathrm{~m}$, 2H, 2 and 5), $1.04(\mathrm{~s}, 3 \mathrm{H}, 8), 1.01(\mathrm{~m}, 2 \mathrm{H}, 3$ and 4), 0.92 (s, 3H, 9); ${ }^{13} \mathrm{C} \mathrm{NMR}\left(\mathrm{CDCl}_{3}, 126 \mathrm{MHz}\right) \delta: 180.9$ (1 and 6), 30.2 (2 and 5), 28.5 (8), 22.0 (3 and 4), 17.3 (7), 15.4 (9). The high-resolution MS (HRMS) (ESI-TOF) mass-to-charge ratio $(m / z)$, calculated for $\mathrm{C}_{9} \mathrm{H}_{14} \mathrm{NaO}_{4}(\mathrm{M}+\mathrm{Na}) 209.0784$, found 209.0788. IR attenuated total reflection (ATR) $v$ : $3013 \mathrm{~cm}^{-1}, 2992 \mathrm{~cm}^{-1}, 2919 \mathrm{~cm}^{-1}, 2868 \mathrm{~cm}^{-1}, 2849 \mathrm{~cm}^{-1}$, $2655 \mathrm{~cm}^{-1}, 2620 \mathrm{~cm}^{-1}, 2591 \mathrm{~cm}^{-1}, 2551 \mathrm{~cm}^{-1}, 1694 \mathrm{~cm}^{-1}$, $941 \mathrm{~cm}^{-1}, 923 \mathrm{~cm}^{-1}, 905 \mathrm{~cm}^{-1}$.

Limonic acid was prepared, starting from (R)-limonene (Aldrich, $97 \%$ purity), which was epoxidised with metachloroperbenzoic acid (Aldrich, 85\%) and $\mathrm{NaHCO}_{3}$ in dichloromethane (DCM) to limonene epoxide (Naves and Grampoloff, 1961). Oxidative ring opening of the epoxide with $\mathrm{NaIO}_{4}$ (Aldrich, 99.8\%) in water-tetrahydrofuran (THF) (Cane et al., 1992) resulted in limonon aldehyde, which was oxidised with $\mathrm{NaClO}_{2}$ (Aldrich, $80 \%$ ) in dimethyl sulphoxide (DMSO) (Binder et al., 2008) to limononic acid. The ketoacid was esterified with ethyl bromide and $\mathrm{NaHCO}_{3}$ in DMSO (Bocchi et al., 1979), and purified by flash chromatography (solvent gradient from pentane to $1: 1 \mathrm{Et}_{2} \mathrm{O}$-pentane) to give ethyl limononate as a colourless oil. Thin-layer chromatography (TLC) $\mathrm{r}_{F}: 0.37$ (EtOAc:hexane $1: 2$, vanillin staining). ${ }^{1} \mathrm{H} \mathrm{NMR}\left(\mathrm{CDCl}_{3}\right.$, $500 \mathrm{MHz}) \delta: 4.77(\mathrm{~d}, \mathrm{~J}=28 \mathrm{~Hz}, 2 \mathrm{H}, 10), 4.10(\mathrm{q}, \mathrm{J}=7.2 \mathrm{~Hz}$, 2H, 11), 2.55 (m, 1H, 5), 2.40-2.31 (m, 4H, 3 and 6), 2.12 $(\mathrm{s}, 3 \mathrm{H}, 1), 1.74-1.67(\mathrm{~m}, 1 \mathrm{H}, 4), 1.64(\mathrm{~s}, 3 \mathrm{H}, 8), 1.64$ $1.58(\mathrm{~m}, 1 \mathrm{H}, 4), 1.23(\mathrm{t}, \mathrm{J}=7.2 \mathrm{~Hz}, 3 \mathrm{H}, 12) ;{ }^{13} \mathrm{C} \mathrm{NMR}$ $(\mathrm{CDCl} 3,126 \mathrm{MHz}) \delta: 208.5$ (s, 2), 172.4 (7), 145.5 (9), 113.0 (10), 60.4 (11), 43.3 (5), 41.3 (3), 39.3 (6), 30.1 (1), 26.4 (4), 18.5 (8), 14.3 (12). HRMS (ESI-TOF) $m / z$, calculated for $\mathrm{C}_{12} \mathrm{H}_{20} \mathrm{NaO}_{3}(\mathrm{M}+\mathrm{Na})$ 235.1305, found 235.1313. IR (ATR) v: $3075 \mathrm{~cm}^{-1}, 2982 \mathrm{~cm}^{-1}, 2937 \mathrm{~cm}^{-1}, 1731 \mathrm{~cm}^{-1}$, $1715 \mathrm{~cm}^{-1}, 1646 \mathrm{~cm}^{-1}, 894 \mathrm{~cm}^{-1}$.

Haloform reaction of ethyl limononate with $\mathrm{NaOBr}$ in dioxane/water (Staunton and Eisenbraun, 1973) yielded limonic acid, which was purified by flash chromatography on silica (solvent gradient from $50: 1 \mathrm{CHCl}_{3}-\mathrm{AcOH}$ to 5:45:1 $\left.\mathrm{MeOH}-\mathrm{CHCl}_{3}-\mathrm{AcOH}\right)$ to give a white solid with a $24 \%$ yield (based on limonene) and $97 \%$ purity (estimated by NMR). Mp. $115-117^{\circ} \mathrm{C}$ (in literature $117-118^{\circ} \mathrm{C}$; Abe, 1943). $[\alpha]_{D}^{22,6}=+7.416\left(\mathrm{c}=0.5, i\right.$-PrOH). ${ }^{1} \mathrm{H} \mathrm{NMR}$ (acetone-d6, $500 \mathrm{MHz}) \delta: 10.48(\mathrm{br}, 2 \mathrm{H}, 1$ and $6 \mathrm{COOH})$, $4.80(\mathrm{~d}, \mathrm{~J}=12 \mathrm{~Hz}, 2 \mathrm{H}, 9), 2.62(\mathrm{~m}, 1 \mathrm{H}, 4), 2.44-2.36(\mathrm{~m}, 2 \mathrm{H}$, 5), 2.31-2.20 (m, 2H, 2), 1.83-1.76 (m, 1H, 3), 1.73-1.65 (m, 1H, 3), 1.70 (s, 3H, 7); ${ }^{13} \mathrm{C}$ NMR (acetone-d6, $\left.126 \mathrm{MHz}\right) \delta$ : 174.5 (1), 173.4 (6), 147.0 (8), 112.8 (9), 43.8 (4), 39.2 (5), 32.0 (2), 28.6 (3), 19.0 (7). HRMS (ESI-TOF) $\mathrm{m} / z$, calculated for $\mathrm{C}_{9} \mathrm{H}_{14} \mathrm{NaO}_{4}(\mathrm{M}+\mathrm{Na})$ 209.0784, found 209.0780 . IR (ATR) v: $3081 \mathrm{~cm}^{-1}, 2976 \mathrm{~cm}^{-1}, 2941 \mathrm{~cm}^{-1}, 2911 \mathrm{~cm}^{-1}$, $2668 \mathrm{~cm}^{-1}, 2573 \mathrm{~cm}^{-1}, 1699 \mathrm{~cm}^{-1}, 1694 \mathrm{~cm}^{-1}, 1647 \mathrm{~cm}^{-1}$, $896 \mathrm{~cm}^{-1}$. 

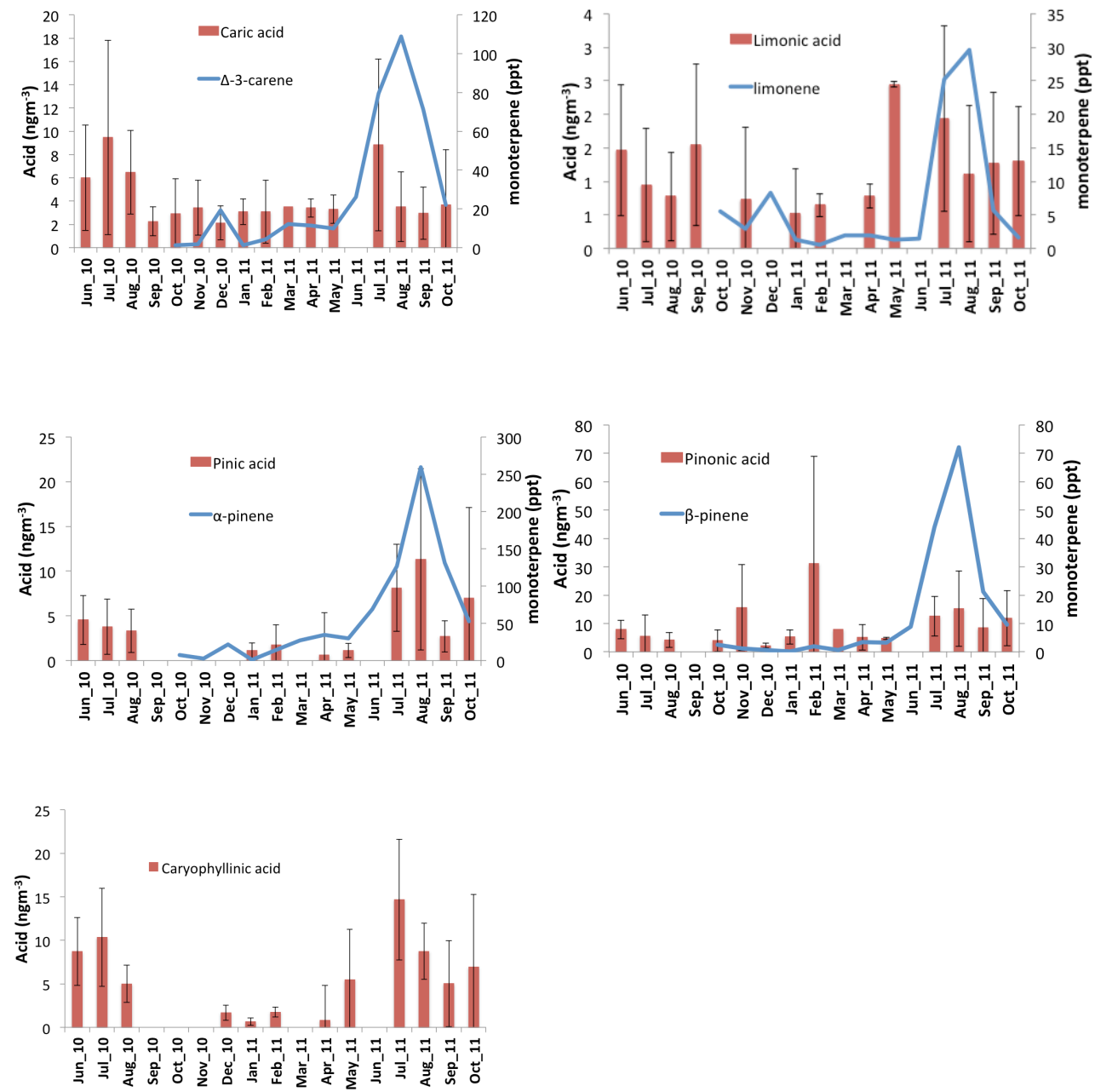

Figure 2. Monthly mean terpenoic acid concentrations and their standard deviations together with monthly mean monoterpene concentrations from Hakola et al. (2012).

$\beta$-caryophyllinic acid was prepared from $\beta$-caryophyllene oxide (Aldrich, $99 \%$ purity) by a method that will be published separately. It was obtained as a glassy solid of $>98 \%$ purity after flash chromatography on silica (solvent gradient from 50:1 $\mathrm{CHCl}_{3}-\mathrm{AcOH}$ to $5: 45: 1$ $\left.\mathrm{MeOH}-\mathrm{CHCl}_{3}-\mathrm{AcOH}\right)$; TLC $\mathrm{r}_{F} 0.62(10: 90: 2 \mathrm{MeOH}-$ $\mathrm{DCM}-\mathrm{AcOH}, \mathrm{Ce}-$ phosphomolybdate staining). ${ }^{1} \mathrm{H}$ NMR $\left(\mathrm{CDCl}_{3}, 500 \mathrm{MHz}\right) \delta: 10.89$ (br, 4 and $\left.5 \mathrm{COOH}\right), 4.76(\mathrm{~s}$, $1 \mathrm{H}, 14), 4.72(\mathrm{~s}, 1 \mathrm{H}, 14), 2.50(\mathrm{t}, \mathrm{J}=7.7 \mathrm{~Hz}, 2 \mathrm{H}, 6), 2.42$ $(\mathrm{q}, \mathrm{J}=9.3 \mathrm{~Hz}, 1 \mathrm{H}, 9), 2.35-2.22(\mathrm{~m}, 4 \mathrm{H}, 3$ and 7$), 1.94(\mathrm{dt}$, $\mathrm{J}=9.2,7.7 \mathrm{~Hz}, 1 \mathrm{H}, 1), 1.81(\mathrm{dd}, \mathrm{J}=8.3 \mathrm{~Hz}, 10.2 \mathrm{~Hz}, 1 \mathrm{H}$, 10), $1.71(\mathrm{q}, \mathrm{J}=7.7 \mathrm{~Hz}, 2 \mathrm{H}, 2), 1.47(\mathrm{t}, \mathrm{J}=10.2 \mathrm{~Hz}, 1 \mathrm{H}$, 10), 1.06 (s, 3H, 12), 1.06 (s, 3H, 13); ${ }^{13} \mathrm{C} \mathrm{NMR}\left(\mathrm{CDCl}_{3}\right.$, $126 \mathrm{MHz}) \delta$ : 180.2 (4), 179.8 (5), 150.5 (8), 107.8 (14), 47.9 (1), 41.8 (9), 39.6 (10), 33.8 (11), 32.6 (6), 32.6 (3), 31.1 (12), 28.9 (7), 25.7 (2), 22.4 (13). HRMS (EI), derivatisation with N,O-bis(trimethylsilyl)trifluoroacetamide (BSTFA) to bis-trimethylsilyl ester, $\mathrm{m} / \mathrm{z}$, calculated for $\mathrm{C}_{20} \mathrm{H}_{38} \mathrm{O}_{4} \mathrm{Si}_{2}\left(\mathrm{M}^{+}\right)$398.2327, found 398.2318. EI-MS (70
eV) m/z (\%): 400 (3), 399 (4), 398 (12) [M], 385 (6), 384 (13), 383 (50) [M- $\left.\mathrm{CH}_{3}\right], 355$ (8) [M- $\left.\mathrm{CH}_{3}-\mathrm{CO}\right], 328$ (7) [M- $\mathrm{C}_{5} \mathrm{H}_{10}$ ], 313 (26), 309 (100), 299 (37), 279 (19), 200 (81) $\left[\mathrm{M}-2\left(\mathrm{C}_{5} \mathrm{H}_{10}\right)\right], 149$ (67) 117 (85).

\section{Results and discussion}

\subsection{Annual variability of terpenoic acids}

The highest terpenoic acid concentrations were measured during summer (Fig. 2), but high concentrations, especially of pinonic acid, were also measured occasionally during winter. Hakola et al. (2012) measured BVOC concentrations at the same site and found occasionally very high BVOC concentrations originating from the nearby sawmills. These emissions cause high concentrations of aerosol particles (Liao et al., 2011), and may cause high acid concentrations as well. Reactions with nitrate radicals at least are fast enough to produce acids in less than half an hour (Hakola et al., 
Table 1. Seasonal mean concentrations (standard deviations) of terpenoic acids from this study and precursor monoterpenes from Hakola et

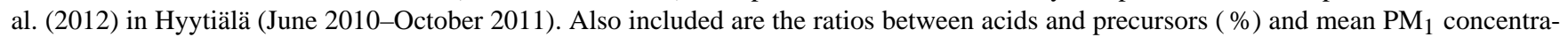
tions.

\begin{tabular}{lllll}
\hline & Winter & Spring & Summer & Autumn \\
\hline Terpenoic acids $\left(\mathrm{ng} \mathrm{m}^{-3}\right)$ & & & & \\
\hline Limonic acid & $0.6(0.5)$ & $1.7(0.9)$ & $1.4(2.4)$ & $1.1(0.9)$ \\
Pinic acid & $1.7(1.4)$ & $2.6(3.2)$ & $7.2(7.3)$ & $3.6(4.8)$ \\
Pinonic acid & $10.2(18)$ & $6.5(3.3)$ & $10.7(13.6)$ & $8.3(9.6)$ \\
Caric acid & $2.6(1.4)$ & $3.6(0.9)$ & $7.2(8.6)$ & $2.9(2.6)$ \\
Caryophyllinic acid & $1.2(0.8)$ & $4.5(4.2)$ & $10.9(12.1)$ & $3.8(5.0)$ \\
\hline Monoterpenes $\left(\mathrm{ng} \mathrm{m}^{-3}\right)$ & & & & \\
\hline$\alpha$-pinene & $40(230)$ & $180(530)$ & $1070(1030)$ & $220(220)$ \\
$\beta$-pinene & $4(30)$ & $20(30)$ & $300(310)$ & $40(40)$ \\
$\alpha$-pinene $+\beta$-pinene & 40 & 200 & 1370 & 260 \\
$\Delta^{3}$-carene & $20(100)$ & $60(230)$ & $480(520)$ & $110(110)$ \\
Limonene & $10(40)$ & $10(40)$ & $130(150)$ & $20(20)$ \\
\hline Ratios $(\%)$ & & & & \\
\hline Pinic acid $/(\alpha$-pinene+ $\beta$-pinene $)$ & 4.3 & 1.3 & 0.5 & 1.4 \\
Pinonic acid $/(\alpha$-pinene+ $\beta$-pinene $)$ & 11 & 3.3 & 0.8 & 3.2 \\
Limonic acid $/$ limonene & 5.5 & 17 & 1.1 & 4.9 \\
Caric acid $/ \Delta^{3}$-carene & 12 & 5.7 & 1.5 & 2.6 \\
PM $1\left(\mu \mathrm{g} \mathrm{m}^{-3}\right)$ & 4.8 & 3.1 & 5.3 & 2.9 \\
\hline & & & & \\
\hline & & & & \\
\hline
\end{tabular}

2003). The results are tabulated in Table 3, which also shows the length of each measurement. Table 1 shows the seasonal average concentrations. Those values below the detection limit were taken as half of the detection limits in the calculation of averages. $\beta$-caryophyllinic acid showed the highest concentrations in summer, but during other times of the year pinonic acid was the most abundant. $\beta$-caryophyllene is emitted mainly in July (Hakola et al., 2006), so the product concentrations are expected to peak at that time too. Limonic acid emissions are distributed more evenly throughout the year, with a maximum already in spring. Scots pine emits only small amounts of limonene, but Norway spruce emits limonene mainly in May (Hakola et al., 2003). There are also a few birches growing in the area, and birches emit limonene in early summer (Hakola et al., 2001). The concentrations were also studied in relation to meteorological parameters, such as temperature, wind speed, relative humidity and the amount of rain at the sampling time, but no clear correlations were found. Averaging over the whole day or several days complicates this inspection.

The acid concentrations were higher in 2011 than in 2010. The temperatures at the time of the measurements were several degrees lower in 2011 than in 2010 (the difference was $2.7^{\circ} \mathrm{C}$ in July and $4.3^{\circ} \mathrm{C}$ in August), and colder temperatures could have caused higher concentrations in the aerosol phase, although the emissions were probably higher at warmer temperatures. Kamens and Jaoui (2001) showed in their simulations and smog chamber experiments with $\alpha$-pinene that decreasing the temperature by $10^{\circ} \mathrm{C}$ increased aerosol yields by a factor of $\sim 2$.

The concentrations of pinonic and pinic acids had relatively good correlation during the summer months $\left(r^{2}=0.42\right)$. This was expected, since they have the same precursors, i.e. they are both reaction products of $\alpha$ - and $\beta$-pinene. The average concentrations for pinonic acid were $40 \%$ higher than for pinic acid. Caric acid and caryophyllinic acid were also somewhat correlated $\left(r^{2}=0.47\right)$ in summer.

The pinic and pinonic acids were also measured previously at the SMEAR II station in short 1- or 2-month campaigns in spring and summer. The results from these previous studies are listed in Table 2. Kourtchev et al. (2008) measured pinic acid in July-August 2005 in the PM $_{1}$ fraction and found a median value of $7.7 \mathrm{ng} \mathrm{m}^{-3}$, which is similar to the summer median in our measurements $\left(6.7 \mathrm{ng} \mathrm{m}^{-3}\right)$. Other results (Warnke et al., 2006; Kourtchev et al., 2008; Parshintsev et al., 2010) also showed values similar to ours.

\subsection{Comparison of terpenoic acids with corresponding monoterpenes}

Ambient monoterpene concentrations were measured at the same site from October 2010 until November 2011 near the filter-sampling site by in situ TD-GC-MS. A detailed description of the monoterpene measurements can be found in Hakola et al. (2012). In Fig. 2, we compared the BVOC mixing ratios with the corresponding acid concentrations and 
Table 2. Concentrations of pinic and pinonic acids in comparison to previous studies at the SMEAR II station in Hyytiälä.

\begin{tabular}{|c|c|c|c|c|}
\hline$n g m^{-3}$ & Pinic acid & Pinonic acid & PM size cutoff & Reference \\
\hline \multicolumn{5}{|l|}{ Spring } \\
\hline Mar/Apr 03 & $1.1-21$ & $0.99-74$ & $\mathrm{PM}_{2.5}$ & Warnke et al. (2006) \\
\hline Mar/Apr 11 & $0.66-7.3$ & $0.5-11$ & $\mathrm{PM}_{2.5}$ & This study \\
\hline \multicolumn{5}{|l|}{ Summer } \\
\hline Jul/Aug 01 & $0.38-4.7$ & $0.91-8.2$ & $\mathrm{PM}_{2.5}$ & Warnke et al. (2006) \\
\hline Jul/Aug 05 & $2-29.6$ & & $\mathrm{PM}_{1}$ & Kourtchev et al. (2008) \\
\hline Aug 07 & $1-7$ & $11-28$ & $\mathrm{PM}_{2.5}$ & Parshintsev et al. (2010) \\
\hline Jul/Aug 10/11 & $0.64-31$ & $0.1-80$ & $\mathrm{PM}_{2.5}$ & This study \\
\hline
\end{tabular}

found that the overall seasonal patterns were similar, although not all the acid peaks were seen in the parent monoterpene data. This was expected, since the measurement times of the VOCs and corresponding acids did not cover whole months and did not always match. In the online VOC measurements, there were several breaks due to malfunction of the instrument, and because the sampling times of the acids were sometimes several days, the overlapping of VOC and acid data is not complete. Comparisons of these seasonal means thus represent approximations only. However, since the daily variation in VOC mixing ratios is quite modest compared with the seasonal variability, comparing VOC and acid concentrations is justified. The seasonal means of the acid and monoterpene concentrations and the ratios between the acids and precursor monoterpenes are tabulated in Table 1.

We calculated the seasonal acid / monoterpene ratios, and they were lower in summer than in winter (Table 1). This could indicate that during cold seasons the acids are partitioned more to the particle phase than to the gas phase, and vice versa during warm seasons. Temperature, together with carbon and oxygen numbers, are known to be controlling factors in phase partitioning of organic acids (Finlayson-Pitts and Pitts, 2000).

Tarvainen et al. (2007) calculated the BVOC emissions in the middle boreal zone in Finland, utilising satellite land-cover information, meteorological data and published emission factors in a Biogenic Emissions Inventory System (BEIS)-type canopy emission model. They did not calculate the emissions for $\beta$-caryophyllene, but rather for total sesquiterpenes. However, in the published sesquiterpene emission rates (Hakola et al., 2006; Tarvainen et al., 2005), $\beta$-caryophyllene was clearly the predominant sesquiterpene species emitted in boreal forests. We compared these emissions with the corresponding acid concentrations (Fig. 3) and found that they were in relatively good agreement. The pinic and pinonic acids and the $\alpha$ - and $\beta$-pinenes are added together, since both of these monoterpenes produce both acids. The caric and limonic acids showed lower contributions than their precursors in the emission calculations. This was expected, since their yields in the smog chamber experiments were lower than the yields of the other acids (Yu et al., 1999; Jaoui et al., 2006, 2003). However, the yield of $\beta$ caryophyllinic acid (Jaoui et al., 2003) was also lower than the pinic and pinonic acid yields, but its contribution was higher than expected, based on the emission calculations, especially since the calculations also included other sesquiterpenes. This could imply that the $\beta$-caryophyllene emissions or $\beta$-caryophyllinic acid yields were underestimated.

\subsection{Comparison with particulate data}

The highest seasonal means for $\mathrm{PM}_{1}$ were observed in summer, together with the highest terpenoic acid concentrations (Table 1), but the measured terpenoic acids explained only a small fraction of the total $\mathrm{PM}_{1}$ mass: $0.2 \%$ in winter and $0.7 \%$ in summer.

The average submicrometre organic carbon (OC) concentration in Hyytiälä in 2007/2008 was $1100 \mathrm{ng} \mathrm{m}^{-3}$ : $1200 \mathrm{ng} \mathrm{m}^{-3}$ in summer and $1300 \mathrm{ng} \mathrm{m}^{-3}$ in winter (Aurela et al., 2011). The sum of the terpenoic acids measured in this study comprised only $0.9-3.4 \%$ of this OC, showing the highest fraction in summer and the lowest in winter. Although the measurements were conducted in different years, we expected that these five terpenoic acids would have only a small impact on the total OC concentrations, especially in winter. However, this fraction was clearly higher than the $0.6 \%$ value for the 12 terpenoic acids found by GomezGonzalez et al. (2012) in summer at a forest site in Belgium.

The acid concentrations were also studied in relation to the particle concentrations in different size fractions. The particle number concentrations were measured in the size range $3-1000 \mathrm{~nm}$ with a differential mobility particle sizer (DMPS), and the $\mathrm{PM}_{1}$ mass concentration was calculated from it (Aalto et al., 2001). No correlation was found between the acid concentrations and the nucleation-mode particles $(3-25 \mathrm{~nm})$ or the Aitken-mode particles $(25-100 \mathrm{~nm})$. In the accumulation-mode particles $(100-1000 \mathrm{~nm})$, the caric $\left(r^{2}=0.28\right)$ and caryophyllinic $\left(r^{2}=0.13\right)$ acids were somewhat correlated with the particle number concentration, as shown in Fig. 4. The $\mathrm{PM}_{1}$ mass 
Table 3. Sampling dates and acid concentrations of all samples.

\begin{tabular}{|c|c|c|c|c|c|c|}
\hline Start & End & $\begin{array}{l}\text { Limonic acid } \\
\mathrm{ng} \mathrm{m}^{-3}\end{array}$ & $\begin{array}{l}\text { Pinic acid } \\
\mathrm{ng} \mathrm{m}^{-3}\end{array}$ & $\begin{array}{l}\text { Pinonic acid } \\
\mathrm{ng} \mathrm{m}^{-3}\end{array}$ & $\begin{array}{l}\text { Caric acid } \\
\mathrm{ng} \mathrm{m}^{-3}\end{array}$ & $\begin{array}{c}\text { Caryophyllinic acid } \\
\mathrm{ng} \mathrm{m}^{-3}\end{array}$ \\
\hline 100604 & 100607 & 0.71 & 4.86 & 8.10 & 2.27 & 10.25 \\
\hline 100607 & 100609 & 1.10 & $<\mathrm{LOD}$ & 7.18 & 5.96 & 6.40 \\
\hline 100609 & 100611 & 1.62 & 0.52 & 11.35 & 14.87 & 12.44 \\
\hline 100611 & 100614 & 0.35 & 2.64 & 13.68 & 1.07 & 13.79 \\
\hline 100614 & 100616 & 2.45 & 7.28 & 6.77 & 9.10 & 13.50 \\
\hline 100616 & 100618 & 1.98 & $<\mathrm{LOD}$ & 3.12 & 4.42 & $<\mathrm{LOD}$ \\
\hline 100621 & 100623 & 0.33 & 7.29 & 8.91 & 1.36 & 5.47 \\
\hline 100628 & 100630 & 1.41 & 4.94 & 4.01 & 5.25 & 5.45 \\
\hline 100630 & 100702 & 3.24 & 7.28 & 8.02 & 9.72 & 8.10 \\
\hline 100705 & 100707 & $<$ LOD & $<$ LOD & $<\mathrm{LOD}$ & 21.13 & 18.77 \\
\hline 100707 & 100709 & $<$ LOD & $<$ LOD & $<\mathrm{LOD}$ & 23.69 & 14.09 \\
\hline 100709 & 100712 & $<\mathrm{LOD}$ & $<\mathrm{LOD}$ & $<$ LOD & $<\mathrm{LOD}$ & $<\mathrm{LOD}$ \\
\hline 100716 & 100719 & $<$ LOD & $<\mathrm{LOD}$ & $<\mathrm{LOD}$ & 4.37 & 5.41 \\
\hline 100719 & 100721 & $<$ LOD & $<$ LOD & $<\mathrm{LOD}$ & 2.43 & $<\mathrm{LOD}$ \\
\hline 100723 & 100726 & 2.08 & 5.77 & 2.46 & 9.30 & 8.89 \\
\hline 100726 & 100728 & 1.29 & 2.34 & 8.50 & 6.27 & 10.36 \\
\hline 100729 & 100730 & 1.46 & 8.53 & 23.21 & 6.73 & 16.05 \\
\hline 100730 & 100802 & 0.72 & 1.78 & 2.22 & 2.22 & 3.67 \\
\hline 100802 & 100804 & 1.97 & 7.28 & 7.35 & 9.39 & 6.13 \\
\hline 100804 & 100806 & 0.88 & 3.49 & 5.74 & 7.59 & 8.82 \\
\hline 100806 & 100809 & 0.74 & 4.86 & 2.07 & 2.25 & 4.14 \\
\hline 100811 & 100813 & $<$ LOD & $<$ LOD & 6.72 & 10.80 & 2.96 \\
\hline 100813 & 100816 & $<\mathrm{LOD}$ & $<\mathrm{LOD}$ & $<\mathrm{LOD}$ & 6.59 & 4.27 \\
\hline 100915 & 100922 & 2.39 & $<\mathrm{LOD}$ & $<\mathrm{LOD}$ & 3.13 & $<\mathrm{LOD}$ \\
\hline 100922 & 100930 & $<$ LOD & $<$ LOD & $<\mathrm{LOD}$ & 1.38 & $<\mathrm{LOD}$ \\
\hline 101004 & 101011 & $<$ LOD & $<\mathrm{LOD}$ & $<\mathrm{LOD}$ & $<\mathrm{LOD}$ & $<\mathrm{LOD}$ \\
\hline 101025 & 101101 & $<\mathrm{LOD}$ & $<\mathrm{LOD}$ & 6.68 & 5.03 & $<\mathrm{LOD}$ \\
\hline 101108 & 101119 & 1.98 & $<\mathrm{LOD}$ & 32.99 & 5.16 & $<\mathrm{LOD}$ \\
\hline 101119 & 101122 & $<$ LOD & $<\mathrm{LOD}$ & 8.27 & 4.43 & $<\mathrm{LOD}$ \\
\hline 101122 & 101129 & 0.15 & 0.15 & 5.50 & 0.74 & 1.30 \\
\hline 101129 & 101207 & $<$ LOD & $<$ LOD & 2.55 & 3.74 & 0.68 \\
\hline 101213 & 101220 & $<$ LOD & $<$ LOD & $<\mathrm{LOD}$ & 1.68 & $<\mathrm{LOD}$ \\
\hline 101227 & 110103 & $<$ LOD & $<\mathrm{LOD}$ & $<\mathrm{LOD}$ & $<$ LOD & $<\mathrm{LOD}$ \\
\hline 110103 & 110110 & 1.47 & 2.12 & 8.65 & 4.05 & 1.15 \\
\hline 110110 & 110117 & $<$ LOD & $<\mathrm{LOD}$ & 4.33 & 2.86 & $<\mathrm{LOD}$ \\
\hline 110118 & 110125 & $<$ LOD & $<\mathrm{LOD}$ & 2.78 & 3.77 & $<\mathrm{LOD}$ \\
\hline 110125 & 110201 & 0.50 & $<\mathrm{LOD}$ & 5.20 & 1.60 & $<\mathrm{LOD}$ \\
\hline 110201 & 110207 & 0.53 & 0.17 & 4.24 & 5.01 & 1.34 \\
\hline 110214 & 110221 & $<\mathrm{LOD}$ & $<\mathrm{LOD}$ & 57.87 & 1.17 & $<\mathrm{LOD}$ \\
\hline 110228 & 110307 & $<$ LOD & $<\mathrm{LOD}$ & 4.40 & 2.50 & $<$ LOD \\
\hline 110328 & 110404 & 1.04 & 7.28 & 11.39 & 4.53 & 6.47 \\
\hline 110426 & 110502 & 0.78 & $<\mathrm{LOD}$ & 5.09 & 3.41 & 0.79 \\
\hline 110502 & 110509 & 2.42 & $<\mathrm{LOD}$ & 4.45 & 2.44 & 1.36 \\
\hline 110516 & 110524 & 2.48 & 1.70 & 5.06 & 4.16 & 9.56 \\
\hline 110630 & 110701 & 3.71 & 29.37 & 35.21 & 18.10 & 30.84 \\
\hline 110701 & 110704 & 16.46 & 16.06 & 80.14 & 49.78 & 86.09 \\
\hline 110704 & 110705 & 0.55 & 21.85 & 23.03 & 0.98 & 7.83 \\
\hline 110705 & 110706 & 1.83 & $<\mathrm{LOD}$ & 23.02 & 4.47 & 7.25 \\
\hline 110706 & 110706 & $<\mathrm{LOD}$ & 0.00 & $<\mathrm{LOD}$ & 14.99 & $<\mathrm{LOD}$ \\
\hline 110711 & 110712 & 5.75 & 9.17 & 9.94 & 28.66 & 32.68 \\
\hline 110712 & 110713 & $<$ LOD & 10.98 & $<\mathrm{LOD}$ & 0.91 & $<\mathrm{LOD}$ \\
\hline 110713 & 110714 & $<$ LOD & 14.48 & $<\mathrm{LOD}$ & $<\mathrm{LOD}$ & $<\mathrm{LOD}$ \\
\hline 110714 & 110715 & $<$ LOD & $<\mathrm{LOD}$ & $<\mathrm{LOD}$ & 1.55 & $<$ LOD \\
\hline 110715 & 110718 & 1.21 & $<\mathrm{LOD}$ & $<\mathrm{LOD}$ & 4.74 & 7.33 \\
\hline
\end{tabular}


Table 3. Continued.

\begin{tabular}{|c|c|c|c|c|c|c|}
\hline Start & End & $\begin{array}{l}\text { Limonic acid } \\
\mathrm{ng} \mathrm{m}^{-3}\end{array}$ & $\begin{array}{l}\text { Pinic acid } \\
\mathrm{ng} \mathrm{m}^{-3}\end{array}$ & $\begin{array}{l}\text { Pinonic acid } \\
\mathrm{ng} \mathrm{m}^{-3}\end{array}$ & $\begin{array}{l}\text { Caric acid } \\
\mathrm{ng} \mathrm{m}^{-3}\end{array}$ & $\begin{array}{l}\text { Caryophyllinic acid } \\
\mathrm{ng} \mathrm{m}^{-3}\end{array}$ \\
\hline 110718 & 110719 & $<\mathrm{LOD}$ & $<\mathrm{LOD}$ & $<\mathrm{LOD}$ & 3.14 & $<\mathrm{LOD}$ \\
\hline 110719 & 110720 & 1.05 & $<\mathrm{LOD}$ & 20.64 & 7.59 & 12.38 \\
\hline 110720 & 110721 & 1.24 & $<\mathrm{LOD}$ & 7.38 & 12.49 & 14.96 \\
\hline 110721 & 110722 & $<$ LOD & $<$ LOD & $<\mathrm{LOD}$ & 8.29 & 8.17 \\
\hline 110725 & 110726 & 0.87 & $<$ LOD & 11.08 & 2.47 & 6.70 \\
\hline 110726 & 110727 & $<\mathrm{LOD}$ & 5.35 & $<$ LOD & 2.61 & $<$ LOD \\
\hline 110728 & 110729 & 1.02 & 16.55 & 12.85 & 3.16 & 13.50 \\
\hline 110729 & 110801 & 0.89 & $<$ LOD & 4.59 & 3.96 & 5.61 \\
\hline 110801 & 110802 & $<$ LOD & 20.71 & 12.70 & 1.86 & 10.84 \\
\hline 110802 & 110803 & 1.82 & 13.81 & 19.38 & 0.53 & 11.06 \\
\hline 110804 & 110805 & $<\mathrm{LOD}$ & $<$ LOD & 22.65 & 8.56 & 11.05 \\
\hline 110805 & 110808 & 0.81 & $<$ LOD & $<\mathrm{LOD}$ & 4.59 & 5.17 \\
\hline 110808 & 110809 & 0.94 & 15.22 & 5.88 & 0.99 & 9.78 \\
\hline 110809 & 110810 & 1.33 & 20.56 & 28.95 & 1.06 & 11.65 \\
\hline 110811 & 110812 & $<$ LOD & $<$ LOD & $<\mathrm{LOD}$ & 6.74 & 9.34 \\
\hline 110815 & 110816 & 3.37 & 31.40 & 43.34 & 3.25 & 12.15 \\
\hline 110816 & 110817 & 2.27 & $<\mathrm{LOD}$ & 20.11 & 8.03 & 6.02 \\
\hline 110818 & 110819 & $<\mathrm{LOD}$ & $<$ LOD & 10.30 & 0.88 & $<\mathrm{LOD}$ \\
\hline 110826 & 110829 & 0.30 & $<\mathrm{LOD}$ & $<\mathrm{LOD}$ & 2.25 & $<\mathrm{LOD}$ \\
\hline 110901 & 110907 & 2.81 & 4.03 & 3.35 & 5.23 & 5.78 \\
\hline 110909 & 110912 & 2.11 & $<$ LOD & 9.65 & 6.00 & 4.66 \\
\hline 110916 & 110919 & $<\mathrm{LOD}$ & $<\mathrm{LOD}$ & $<\mathrm{LOD}$ & 1.92 & $<\mathrm{LOD}$ \\
\hline 110919 & 110921 & $<$ LOD & $<$ LOD & $<\mathrm{LOD}$ & 1.18 & $<\mathrm{LOD}$ \\
\hline 100922 & 100923 & $<\mathrm{LOD}$ & $<\mathrm{LOD}$ & $<\mathrm{LOD}$ & $<$ LOD & $<\mathrm{LOD}$ \\
\hline 110929 & 110930 & 1.48 & 5.29 & 28.75 & 2.97 & 14.41 \\
\hline 110930 & 111003 & 2.72 & $<$ LOD & $<\mathrm{LOD}$ & 4.70 & 0.85 \\
\hline 111005 & 111006 & $<$ LOD & 7.82 & 19.62 & $<$ LOD & 16.50 \\
\hline 111007 & 111010 & $<$ LOD & $<$ LOD & $<$ LOD & 1.36 & 1.46 \\
\hline 111011 & 111018 & $<$ LOD & $<$ LOD & $<\mathrm{LOD}$ & $<$ LOD & $<\mathrm{LOD}$ \\
\hline 111026 & 111028 & $<$ LOD & $<$ LOD & 24.37 & 10.53 & $<\mathrm{LOD}$ \\
\hline
\end{tabular}

Figure 3. Relative contributions of terpenoic acids in summer (left) and average terpenoid emission fluxes (right) from middle boreal zone forests in summer from Tarvainen et al. (2007).

concentration correlated weakly with the caric $\left(r^{2}=0.28\right)$ and caryophyllinic $\left(r^{2}=0.1\right)$ acids. The pinic and pinonic acids did not correlate with any particle-size fractions. Smog chamber studies showed that pinonic and pinic acids are partitioned more to the gas phase than the other studied acids (Yu et al., 1999).

\section{Conclusions}

The highest terpenoic acid concentrations were measured in summer. The results were compared with the parent monoterpene and sesquiterpene mixing ratios. Pinonic and $\beta$-caryophyllinic acids were the most abundant acids in summer. The $\beta$-caryophyllinic acid contribution was higher than expected, based on the emission calculations and smog 

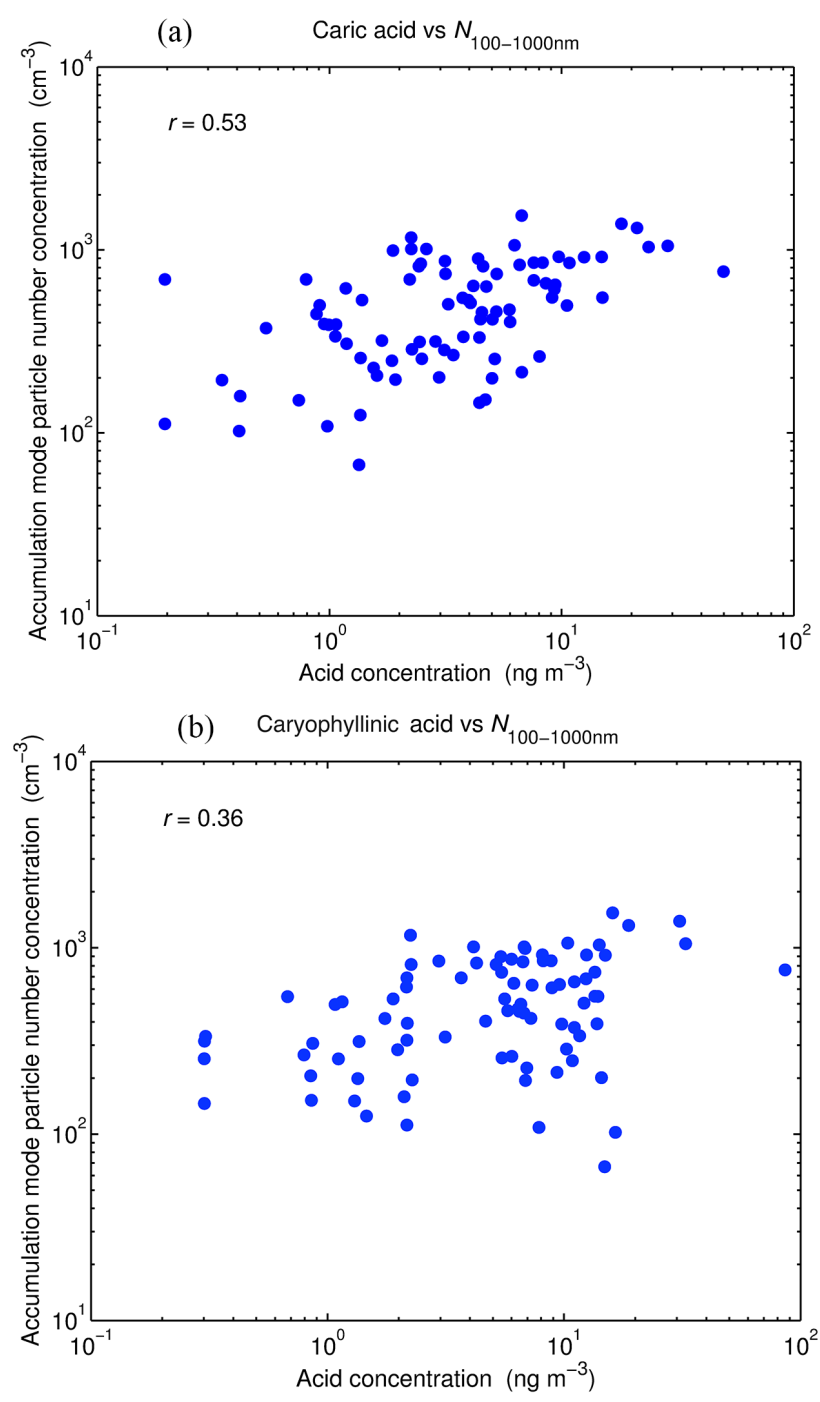

Figure 4. Correlations between caric acid (a) and $\beta$-caryophyllinic acid (b) and the accumulation-mode particle number concentrations.

chamber yields, implying that the $\beta$-caryophyllene emissions and/or $\beta$-caryophyllinic acid yields were underestimated. The limonic acid concentration peaked already in spring, which is in accordance with the measured limonene emissions from Norway spruce, which also reach their maximum in spring. The pinonic and limonic acids also showed quite high concentrations in winter. These winter concentrations may be of anthropogenic origin. Higher ratios between the terpenoic acids and their precursors in winter indicated higher partitioning to the aerosol phase during the colder winter months.

These five terpenoic acids comprised only a small fraction $(\sim 1-3 \%)$ of the total OC in particles measured at the site, and only $0.2-0.7 \%$ of the $\mathrm{PM}_{1}$ mass. The $\beta$ caryophyllinic and caric acids were weakly correlated with the accumulation-mode particle number concentrations, im- plying that they participated in the particle growth process, which is crucial for the formation of cloud condensation nuclei.

Acknowledgements. Financial support by the Academy of Finland Centre of Excellence programme (project no. 1118615) is gratefully acknowledged. The authors also gratefully acknowledge the Tor and Maj Nessling Foundation for supporting this project financially.

We thank Valtteri Vuorikoski for his assistance in Japanese translation.

Edited by: S. A. Nizkorodov

\section{References}

Aalto, P. P., Hämeri, K., Becker, E., Weber, R., Salm, J., Mäkelä, J. M., Hoell, C., O’Dowd, C. D., Karlsson, H., Hansson, H.-C., Väkevä, M., Koponen, I., Buzorius, G., and Kulmala, M.: Physical characterization of aerosol particles during nucleation events, Tellus, 53B, 344-358, 2001.

Abe, S.: The chemical constitution of the perillaldehyde, the component of the oil of Perilla nankinensis, Nippon Kagaku Kaishi, 64, 845-847, 1943.

Aurela, M., Saarikoski, S., Timonen, H., Aalto, P., Keronen, P., Saarnio, K., Teinila, K., Kulmala, M., and Hillamo, R.: Carbonaceous aerosol at a forested and an urban background sites in Southern Finland, Atmos. Environ., 45, 1394-1401, 2011.

Binder, C. M., Dixon D. D., Almaraz E., Tius, M. A., and Singaram, B.: A simple procedure for $\mathrm{C}-\mathrm{C}$ bond cleavage of aromatic and aliphatic epoxides with aqueous sodium periodate under ambient conditions, Tetrahedron Lett., 49, 2764-2767, 2008.

Bocchi, V., Casnati, G., Dossena, A., and Marchelli, R.: Esterification of amino acids and dipeptides under mild conditions; Part II: via sodium salts, Synthesis, 1979, 961-962, 1979.

Cane, D. E., Yang, G., Coates, R. M., Pyun, H.-J., and Hohn, T. M.: Trichodiene synthase. Synergistic inhibition by inorganic pyrophosphate and aza analogs of the bisabolyl cation, J. Org. Chem., 57, 3454-3462, 1992.

Chen, Q., Li, Y. L., McKinney, K. A., Kuwata, M., and Martin, S. T.: Particle mass yield from ?-caryophyllene ozonolysis, Atmos. Chem. Phys., 12, 3165-3179, doi:10.5194/acp-12-31652012, 2012.

Cheng, Y., Brook, J. R., Li, S.-L., and Leithead, A.: Seasonal variation in the biogenic secondary organic aerosol tracer cis-pinonic acid: Enhancement due to emissions from regional and local biomass burning, Atmos. Environ., 45, 7105-7112, 2011.

Finlayson-Pitts, B. J. and Pitts, J. N.: Chemistry of the upper and lower atmosphere, Academic Press, San Diego, CA, 412-417, 2000.

Fu, P., Kawamura, K., Chen, J., and Barrie, L. A.: Isoprene, monoterpene, and sesquiterpenes oxidation products in the high arctic aerosols during late winter to early summer, Environ. Sci. Technol., 43, 4022-4028, 2009.

Gómez-González, Y., Wang, W., Vermeylen, R., Chi, X., Neirynck, J., Janssens, I. A., Maenhaut, W., and Claeys, M.: Chemical characterisation of atmospheric aerosols during a 2007 summer field campaign at Brasschaat, Belgium: sources and source processes 
of biogenic secondary organic aerosol, Atmos. Chem. Phys., 12, 125-138, doi:10.5194/acp-12-125-2012, 2012.

Griffin, R. J., Cocker III, D. R., Flagan, R. C., and Seinfeld, J. H.: Organic aerosol formation from the oxidation of biogenic hydrocarbons, J. Geophys. Res., 104, 3555-3567, 1999.

Hakola, H., Laurila, T., Lindfors, V., Hellén H. Gaman, A., and Rinne, J.: Variation of the VOC emission rates of birch species during the growing season, Boreal. Environ. Res., 6, 237-249, 2001.

Hakola, H., Tarvainen, V. Laurila, T., Hiltunen, V., Hellén, H. and Keronen, P.: Seasonal variation of VOC concentrations above a boreal coniferous forest, Atmos. Environ., 37, 1623-1634, 2003.

Hakola, H., Tarvainen, V., Bäck, J., Ranta, H., Bonn, B., Rinne, J., and Kulmala, M.: Seasonal variation of mono- and sesquiterpene emission rates of Scots pine, Biogeosciences, 3, 93-101, doi:10.5194/bg-3-93-2006, 2006.

Hakola, H., Hellén, H., Hemmilä, M., Rinne, J., and Kulmala, M.: In situ measurements of volatile organic compounds in a boreal forest, Atmos. Chem. Phys., 12, 11665-11678, doi:10.5194/acp12-11665-2012, 2012.

Hallquist, M., Wenger, J. C., Baltensperger, U., Rudich, Y., Simpson, D., Claeys, M., Dommen, J., Donahue, N. M., George, C., Goldstein, A. H., Hamilton, J. F., Herrmann, H., Hoffmann, T., Iinuma, Y., Jang, M., Jenkin, M. E., Jimenez, J. L., Kiendler-Scharr, A., Maenhaut, W., McFiggans, G., Mentel, Th. F., Monod, A., Prévôt, A. S. H., Seinfeld, J. H., Surratt, J. D., Szmigielski, R., and Wildt, J.: The formation, properties and impact of secondary organic aerosol: current and emerging issues, Atmos. Chem. Phys., 9, 5155-5236, doi:10.5194/acp-9-51552009, 2009.

Hari, P. and Kulmala, M.: Station for measuring ecosystematmosphere relations (SMEAR II), Boreal Environ. Res., 10, 315-322, 2005.

Hellén, H., Hakola, H., Pystynen, K.-H., Rinne, J., and Haapanala, S.: $\mathrm{C}_{2}-\mathrm{C}_{10}$ hydrocarbon emissions from a boreal wetland and forest floor, Biogeosciences, 3, 167-174, doi:10.5194/bg-3-1672006, 2006.

Jaoui, M., Leungsakul, S., and Kamens, R. M.: Gas and particle products distribution from the reaction of $\beta$-caryophyllene with ozone, J. Atmos. Chem., 45, 261-287, 2003.

Jaoui, M. and Kamens, R. M.: Gaseous and particulate oxidation products analysis of a mixture of alpha-pinene plus betapinene $/ \mathrm{O}_{3}$ /air in the absence of light and alpha-pinene plus betapinene/ $\mathrm{NO}_{\mathrm{x}} /$ air in the presence of natural sunlight, J. Atmos. Chem., 44, 259-297, 2003.

Jaoui, M., Corse, E., Kleindienst, T. E., Offenberg, J. H., Lewandowski, M., and Edney, E. O.: Analusis of secondary organic aerosol compounds from the photooxidation of d-limonene in the presence of $\mathrm{NO}_{\mathrm{x}}$ and their detection in ambient $\mathrm{PM}_{2.5}$, Environ. Sci. Technol., 40, 3819-3828, 2006.

Kamens, R. M. and Jaoui, M.: Modeling aerosol formation from apinene $+\mathrm{NO}_{\mathrm{x}}$ in the presence of natural sunlight using gas-phase kinetics and gas-particle pertitioning theory, Environ. Sci. Technol., 35, 1394-1405, 2001.

Kanakidou, M., Seinfeld, J. H., Pandis, S. N., Barnes, I., Dentener, F. J., Facchini, M. C., Van Dingenen, R., Ervens, B., Nenes, A., Nielsen, C. J., Swietlicki, E., Putaud, J. P., Balkanski, Y., Fuzzi, S., Horth, J., Moortgat, G. K., Winterhalter, R., Myhre, C. E. L., Tsigaridis, K., Vignati, E., Stephanou, E. G., and Wilson,
J.: Organic aerosol and global climate modelling: a review, Atmos. Chem. Phys., 5, 1053-1123, doi:10.5194/acp-5-1053-2005, 2005.

Kavouras, I. G. and Stephanou, E. G.: Particle size distribution of organic primary and secondary aerosol constituents in urban, background marine, and forested atmosphere, J. Geophys. Res., 107, doi:10.1029/2000JD000278, 2002.

Kourtchev, I., Ruuskanen, T. M., Keronen, P., Sogacheva, L., Dal Maso, M., Reissell, A., Chi, X., Vermeylen, R., Kulmala, M., Maenhaut, W., and Claeys, M.: Determination of isoprene and a-/b-pinene oxidation products in boreal forest aerosols from Hyytiälä, Finland: diel variations and possible link with particle formation events, Plant Biol., 10, 138-149, 2008.

Kourtchev, I., Copolovici, L., Claeys, M., and Maenhaut, W.: Characterization of Atmospheric Aerosols at a Forested Site in Central Europe, Environ. Sci. Technol., 43, 4665-4671, 2009.

Kristensen, K. and Glasius, M.: Organosulfates and oxidation products from biogemic hydrocarbons in fine aerosols from a forest in North West Europé during spring, Atmos. Environ., 45, 45464556, 2011.

Kulmala, M., Suni, T., Lehtinen, K. E. J., Dal Maso, M., Boy, M., Reissell, A., Rannik, Ü., Aalto, P., Keronen, P., Hakola, H., Bäck, J., Hoffmann, T., Vesala, T., and Hari, P.: A new feedback mechanism linking forests, aerosols, and climate, Atmos. Chem. Phys., 4, 557-562, doi:10.5194/acp-4-557-2004, 2004.

Lee, A., Goldstein, A. H. Kroll, J. H., Ng, N. L., Varutbangkul, V., Flagan, R. C., and Seinfeld, J. H.: Gas-phase products and secondary aerosol yields from the photooxidation of 16 different terpenes, J. Geophys. Res., 111, D17305, doi:10.1029/2006JD007050, 2006.

Liao, L., Dal Maso, M., Taipale, R., Rinne, J., Ehn, M., Junninen, H., Äijälä, M., Nieminen, T., Alekseychik, P., Hulkkonen, M., Worsnop, D. R., Kerminen, V.-M., and Kulmala, M.: Monoterpene pollution episodes in a forest environment: indication of anthropogenic origin and association with aerosol particles, Boreal Environ. Res., 16, 288-303, 2011.

Nair, L. G., Saksena, A., Lovey, R., Sannigrahi, M., Wong, J., Kong, J., Fu, X., and Girijavallabhan, V.: A facile and efficient synthesis of 3,3-dimethyl isopropylidene proline from (+)-3-carene, J. Org. Chem., 75, 1285-1288, 2010.

Naves, Y.-R. and Grampoloff, A.-V.: Etudes sur les matières végétales volatiles CLXXV. Sur les produits obtenus à partir de l'ozonolyse du (+)- $\Delta$ 3-carène, Helv. Chim. Acta, 44, 637-642, 1961.

Parshintsev, J., Hyötyläinen, T., Hartonen, K., Kulmala, M., and Riekkola, M.-L.: Solid-phase extraction of organic compounds in atmospheric aerosol particles collected with the particleinto-liquid sampler and analysis by liquid chromatography-mass spectrometry, Talanta, 80, 1170-1176, 2010.

Semmler, F. W. and von Schiller, H.: Beiträge zur Kenntnis des ätherischen Öles aus den Kienstubben und Wurzeln von Pinus silvestris (Kiefernwurzelöl) und sein Vergleich mit Stamm- und Nadelölen dieser Pinus-Art, Ber. Dtsch. Chem. Ges. B, 60, 15911607, 1927.

Staunton, J. and Eisenbraun, E. J.: 3- $\beta$-Acetoxyetienic acid [3- $\beta$ Acetoxy-5-androstene-17 $\beta$-carboxylic acid], Org. Synth. Coll., V, 8-11, 1973. 
Steiner, A. H. and Goldstein, A. L.: Biogenic VOCs, in: Volatile organic compounds in the atmosphere, edited by: Koppmann, R., Blackwell Publishing Ltd, Oxford, 82-128, 2007.

Tarvainen, V., Hakola, H., Hellén, H., Bäck, J., Hari, P., and Kulmala, M.: Temperature and light dependence of the VOC emissions of Scots pine, Atmos. Chem. Phys., 5, 989-998, doi:10.5194/acp-5-989-2005, 2005.

Tarvainen, V., Hakola, H., Rinne, J., Hellén, H., and Haapanala, S.: Towards a comprehensive emission inventory of the Boreal forest, Tellus, 59 B, 526-534, 2007

Tunved, P., Hansson, H.-C., Kerminen, V.-M., Ström, J., Dal Maso, M., Lihavainen, H., Viisanen, Y., Aalto, P. P., Komppula, M., and Kulmala, M.: High natural aerosol loading over boreal forests, Science 312, 261-263, 2006.

Yu, J., Cocker III, D. R., Griffin, R. J., Flagan, R. C., and Seinfeld, J. H.: +Gas-phase ozone oxidation of monoterpenes: Gaseous and particulate products, J. Atmos. Chem., 34, 207-258, 1999.
Warnke, J., Bandur, R., and Hoffmann, T.: Capillary-HPLC-ESIMS/MS method for the determination of acidic products from the oxidation of monoterpenes in atmospheric aerosol samples. Anal. Bioanal. Chem., 385, 34-45, 2006.

Wiedinmyer, C., Guenther, A., Harley, P., Hewitt, N., Geron, C., Artaxo, P., Steinbrecher, R., and Rasmussen, R.: Global organic emissions from vegetation, in: Emissions of atmospheric trace compounds, edited by: Granier, C., Artaxo, P., and Reeves, C. E., Kluwer Academic Publishers, Dordrecht, the Netherlands, 115170, 2004

Zhang, Y. Y., Müller, L., Winterhalter, R., Moortgat, G. K., Hoffmann, T., and Pöschl, U.: Seasonal cycle and temperature dependence of pinene oxidation products, dicarboxylic acids and nitrophenols in fine and coarse air particulate matter, Atmos. Chem. Phys., 10, 7859-7873, doi:10.5194/acp-10-7859-2010, 2010. 